\title{
Editorial V.12 n.23
}

Sandra Regina Rech

Doutora, Universidade do Estado de Santa Catarina / sandra.rech@udesc.br Orcid: 0000-0002-0062-6914 / http://lattes.cnpq.br/9014663736269712

\section{Daniela Lucena}

Doutora, Universidad de Buenos Aires / daniela.lucena@gmail.com

Orcid: 0000-0003-0353-3550

\section{Laura Zambrini}

Doutora, Universidad de Buenos Aires / laura.zambrini@gmail.com

Orcid: 0000-0002-9523-7080 / http://lattes.cnpq.br/7402581201959272 


\section{PINTO FLORES PARA QUE ASI NO MUERAN.}

Frida Kahlo

Iniciamos o ano com muitas novidades: nova equipe técnica, novos consultores, novo layout, novos indexadores e a divulgação de quatro edições anuais, ou seja, dois Dossiês temáticos (janeiro e julho) e duas publicações Variata (abril e outubro). Portanto, estamos seguindo o conselho da inspiradora Frida Kahlo: pintando flores para permanecermos ativos. E, neste primeiro número de 2019, a moda estabelece ligações permanentes com as linguagens da arte e do design. No entanto, nem sempre foi concedido o devido reconhecimento nessas áreas e campos de conhecimento. Mesmo na academia, há uma lacuna em tomar a moda como objeto de estudo e fonte legítima de conhecimento.

$\mathrm{Na}$ tentativa de preencher esse espaço, o presente dossiê convida os leitores a ler trabalhos que enfocam sua análise nos complexos laços e intersecções entre moda, arte e design. Em particular, desde o início do século $X X$, as iniciativas estavam localizadas na intersecção de práticas artísticas, arquitetura, design e moda. Esses episódios mostram criações frutíferas, mas também de resistências, discrepâncias e discussões que, em muitos casos, não foram resolvidas. Nesta diretriz, apresentamos aqui artigos que trazem novas questões, visões, casos, leituras e hipóteses que questionam as particularidades dessas relações ambíguas. São colaborações acadêmicas, fruto principalmente de pesquisas realizadas no Brasil e na Argentina, refletindo sobre experiências históricas e contemporâneas baseadas nos diálogos e tensões entre as diferentes disciplinas. Especificamente, o trabalho "Aspectos Artísticos Da Azulejaria Portuguesa Por Meio Do Design Têxtil 
E De Superfície Na Moda" descreve e analisa a impressão artística da produção de azulejos portugueses no design têxtil e da moda brasileira contemporânea. Por sua parte, "Today Your Style, Tomorrow The World: Punk, Moda e Imaginário Visual" reconstrói o legado do movimento punk analisando o papel particular desta contracultura mítica na inovação da moda e da imagem visual contemporânea.

Por sua vez, o texto "¿Cómo los intelectuales conquistaron la moda? Discursos decimonónicos" nos convida a repensar a tensão histórica entre o campo intelectual e o da moda. Ou seja, longe daquele imaginário que descreve a moda como um fenômeno frívolo e intransigente, a autora mostra como, desde o século XIX, a noção de moda tem sido um conceito politizado de que diferentes atores políticos e culturais carregam significados particulares. Seguindo na linha de reflexões sobre vestuário como ato político, o artigo "Vestir el cuerpo en Cautiverio: una práctica por revelar" tem por objetivo estudar as narrativas e testemunhos de detentos em centros de detenção clandestinos durante a última ditadura militar argentina, com foco nas trocas e mutações que eles produziam nas roupas e tecidos que os cobriam, a fim de revelar quais sentidos essas ações poderiam ter no contexto particular do confinamento forçado. Por fim, em relação às ilustrações de moda, a obra "Percepção e Expressão no Universo das Ilustrações de Moda" analisa a linguagem visual, estética e formal nas obras da artista Laura Laine.

Tratam-se, enfim, de artigos que, a partir de objetos e perspectivas de estudos diversos, fornecem caminhos para a compreensão da dinâmica da produção e circulação de bens, materiais e simbólicos, em nossas sociedades contemporâneas e em nossa região. 
Esperamos que a seleção, aqui apresentada, contribua para fomentar a construção do conhecimento nas áreas da Arte, da Moda e do Design e o convidamos, nobre leitor, a percorrer estas páginas e nos ajudar na disseminação deste conteúdo, com votos de uma inspiradora leitura! 